\title{
ANALISIS PRODUK, HARGA, DISTRIBUSI DAN PROMOSI YANG BERPENGARUH TERHADAP KEPUASAN KONSUMEN UNTUK MENGURANGI PERPINDAHAN MEREK PADA A\&W RESTAURANT MASPION SQUARE PERIODE 2015-2018
}

\author{
* Danang Prastiya Cahyadinata, Cholifah, Sutopo \\ Prodi Manajemen Fakultas Ekonomi dan Bisnis Universitas Bhayangkara, Indonesia
}

DOI: $10.46821 /$ benchmark.v1i1.22

\begin{abstract}
Abstrak
Penelitian ini bertujuan untuk mengetahui seberapa besar tingkat kepuasan konsumen yang ada di A\&W Restaurant Periode 2015-2018, penelitian ini dilakukan dengan menggunakan metode kualitatif. Data yang diteliti berupa laporan yang didapatkan dari seorang Manager A\&W Restaurant, data yang berhubungan dengan variabel yang saya teliti. Hasil penelitian dapat ditinjau dari sebuah hasil penelitian yang berhubungan dengan kepuasan konsumen dengan beberapa faktor diantaranya Produk, Harga, Distribusi dan Promosi Terhadap Kepuasan Konsumen untuk mengurangi perpindahan merek. Pada kesimpulan keseluruhan dari analisis yang sudah dilakukan di A\&W Restaurant Giant Maspion Square bahwa Produk, Harga, Distribusi dan Promosi sangat berpengaruh signifikan terhadap Kepuasan Konsumen untuk mengurangi perpindahan merek.
\end{abstract}

Kata kunci : Produk, harga, distribusi dan promosi, kepuasan konsumen

\begin{abstract}
A \& W Restaurant Period 2015-2018, This research was conducted using qualitative methods. Data taken from reports obtained from the A \& W Restaurant Manager, data related to the variables that I examined. The results of the study, can be reviewed from the results of research related to customer satisfaction with several factors, products, prices, distribution and promotion of customer satisfaction to replace brand relationships. At conclusions The overall analysis that has been carried out at A \& W Restaurant Giant Maspion Square because Products, Prices, Distribution and Promotion has a significant effect on Consumer Satisfaction to improve brand distribution.
\end{abstract}

Keywords: Product, prize, distribution and promotion, customer satisfaction

\section{PENDAHULUAN}

Pemasaran merupakan salah satu dari kegiatan pokok yang dilakukan oleh para pengusaha dalam usahanya untuk mempertahankan kelangsungan hidupnya, untuk berkembang dan untuk mendapatkan laba. Berhasil tidaknya dalam pencapaian tujuan bisnis tergantung kepada keahlian pengusahan dibidang pemasaran, produksi, keuangan maupun bidang lain. Selain itu tergantung pula pada kemampuan pengusaha untuk mengkombinasikan fungsi-fungsi tersebut agar usaha perusahan dapat berjalan dengan lancar. Pada dasarnya tujuan dalam mendirikan perusahaan adalah mencari laba semaksimal mungkin. Keberhasilan suatu perusahaan dalam mencapai tujuan sangat berpengaruh oleh kemampuan perusahaan dalam memasarkan produknya. Perusahaan

*Corresponding Author:

Hal: 33-39

Email: danangcahyadinata17@gmail.com 

diharapkan, akan mampu mengatasi tantangan dari pada pesaing terutama dalam bidang pemasaran.

Sejalan dengan berkembangnya perekonomian suatu negara banyak kemajuan dan perubahan yang terjadi dalam dunia bisnis yaitu pada cara membagi pasar (segmentasi) dan cara mengoptimalkan pasar (targetting). Seperti dalam situasi kompetisi pada saat ini, perusahaan dihadapkan pada kebutuhan untuk mengubah strategi pemasarannya. Perubahan dan kemajuan secara tidak langsung akan mempengaruhi suatu perubahan dalam mempertahankan pangsa pasar, akibatnya timbul persaingan antar perusahaan dalam menawarkan produknya di pasar. Persaingan bisnis yang dihadapi perusahaanperusahaan pada saat ini semakin ketat sehingga menuntut manajemen perusahaan untuk lebih cermat dalam menentukan strategi pemasaran agar dapat memenangkan persaingan yang semakin kompetitif. Pada saat ini produk yang berupa jasa telah menjadi bagian yang cukup dominan pegaruhnya di dalam perekonomian di samping produk dalam artian fisik. Semakin maju tingkat peradaban dan tingkat pertumbuhan ekonomi masyarakat, maka jasa atau service menjadi bagian dari kebutuhan hidupnya. Dinegaranegara maju sektor jasa telah berkembang dengan pesat, mulai dari jasa perbankan, jasa pendidikan, jasa konsutasi bisnis, jasa keamanan, jasa percetakan, jasa kesehatan dan lain sebagainya.

Menurut Kotler dalam Fandy Tjiptono (2016:284), mengungkapkan ada lima faktor dominan atau penentu kualitas pelayanan jasa, kelima faktor dominan tersebut diantaranya yaitu :

1. Berwujud (Tangible), yaitu berupa penampilan fisik, peralatan dan berbagai materi komunikasi yang baik.

2. Empati (Empathy), yaitu ketersediaan karyawan dan pengusaha untuk lebih peduli memberikan perhatian secara pribadi kepada pelanggan. Misalnya karyawan harus mencoba menempatkan diri sebagai pelanggan. Jika pelanggan mengeluh maka harus segera dicari solusi segera, agar selalu terjaga hubungan harmonis, dengan menunjukan rasa peduli yang tulus. Dengan cara perhatian yang diberikan para pegawai dalam melayani dan memberikan tanggapan atas keluhan para konsumen.

3. Cepat tanggap (Responsiveness), yaitu kemauan dari karyawan dan pengusaha untuk membantu pelanggan dan memberikan jasa dengan cepat serta mendengar dan mengatasi keluhan konsumen. Dengan cara keinginan para pegawai dalam membantu dan memberikan pelayanan dengan tanggap, kemampuan memberikan pelayanan dengan cepat dan benar, kesigapan para pegawai untuk ramah pada setiap konsumen.

4. Keandalan (Reliability), yaitu kemampuan untuk memberikan jasa susuai dengan yang dijanjikan, terpercaya dan akurat serta konsisten. Contoh dalam hal ini antara lain, kemampuan pegawai dalam meberikanpelayanan yang terbaik, kemampuan pegawai dalam menangani kebutuhan konsumen dengan cepat dan benar, kemampuan perusahaan dalam memberikan pelayanan yang baik sesuai dengan harapan konsumen.

5. Kepastian (Assurance), yaitu berupa kemampuan karyawan untuk menimbulkan keyakinan dan kepercayaan terhadap janji yang telah dikemukakan kepada konsumen. Contoh dalam hal ini antara lain, pengetahuan dan keterampilan pegawai dalam menjalankan tugasnya, pegawai dapat diandalkan, pegawai dapat memberikan 
Memasuki perdagangan bebas AFTA (Asean Free Trade Assosiaotion) tahun 2003 yang lalu sampai sekarang, hampir semua organisasi bisnis menghadapi persaingan dan tantangan dalam kondisi saat ini, diperlukan strategi pemasaran berorientasi pasar yang dapat mengantispasi seluruh kegiatan konsumen, mengatasi ancaman persaingan, dan memperkuat huungan bersaing.

Inti dari utama kegiatan pemasaran yang dikenal luas adalah bauran pemasaran (marketing mix), yang mencakup 4P (Product, Price, Place, Promotion). Keempat variable tersebut merupakan kombinasi yang mempunyai peran yang sama dan merupakan satu kesatuan guna menjunjung sukses perusahaan. Karena itu product, price, place, promotion dapat digunakan oleh perusahaan yang bersangkutan untuk menyusun strategi dasar perusahaan yang dapat menjadi acuan bagi penyusunan strategi pemasaran yang efektif. Pada pelaksaaannya alat pemasaran (marketing mix) tersebut dilakukan secara berbeda-beda dan unik, tetapi tujuan akhir dari marketing mix tersebut adalah meningkatkan penjualan produk yang dihasilkan oleh perusahaan tersebut dan menghasilkan laba.

\section{METODE PENELITIAN}

Inti dari pemasaran adalah mengidentifikasikan dan memenuhi kebutuhan dan keinginan konsumen. Definisi yang baik dan singkat dari pemasaran yang menurut Kotler dan Keller (2016:27) adalah "marketing is meeting needs profitability", maksud ungkapan tersebut adalah pemasaran merupakan hal yang dilakukan untuk memenuhi setiap kebutuhan (kebutuhan konsumen) dengan cara-cara yang menguntungkan semua pihak. Definisi formal yang ditawarkan America Marketing Association (AMA) yang dikutip oleh Kotler dan Keller (2016:27) sebagai berikut : "Marketing is the activity, set of institutions, and processes for creating, communicating, delivering, and exchanging offerings that have value for customers, clients, partners, and society at large". Arti dari definisi tersebut, "pemasaran adalah suatu fungsi organisasi dan serangkaian proses untuk menciptakan, mengkomunikasikan, menghantarkan dan memberikan nilai pelanggan yang unggul".

Menurut (Kotler dan Amstrong, 2014:248) "Produk (Product) adalah segala sesuatu yang dapat ditawarkan kepadapasar agar menarik perhatian, akuisisi, penggunaan, atau konsumsi yang dapat memuaskan suatu keinginan atau kebutuhan”. Saat ini semua produsen memahami begitu pentingnya peranan dan arti kualitas produk yang unggul untuk memenuhi harapan pelangga pada semua aspek produk yang dijual ke pasar.

Dalam proses jual beli harga menjadi salah satu bagian terpenting, karena harga adalah alat tukar dalam transaksi. Harga merupakan satu-satunya unsur bauran pemasaran yang sifatnya fleksibel dimana setiap saat dapat berubah-ubah. Harga juga merupakan salah satu faktor persaingan dalam memasarkan produk. Menurut Kotler dan Armstrong (2012:314) harga adalah "The amount of money charged for a ptoduct or service, the sum of the values that customers exchange for the benefit of having or using the product or service". (Jumlah uang yang dibebankan untuk produk atau layanan, jumlah nilai yang ditukar pelanggan untuk kepentingan memiliki atau menggunakan produk atau layanan) Asumsi Penelitian Guna melengkapi dari hasil penelitian ini, maka asumsi yang dipakai adalah: 
a. Sumber data tetap dan tidak berubah selama penelitian

b. Penelitian ini dilakukan pada A\&W Maspion Square Surabaya Unit Analisis

Unit analisis data sesuatu yang berkaitan dengan fokus yang diteliti. Unit analisis suatu penelitian dapat berupa benda, individu, kelompok, wilayah dan waktu tertentu sesuai dengan fokus penelitiannya. Dalam penelitian ini unit analisis berupa individu dan kelompok, yaitu melakukan pengumpulan data dengan melakukan interview terhadap Manager Restaurant A\&W Maspion Square Surabaya tentang peranan promosi terhadap volume penjualan. Dengan dibatasi subyek yang dikaji, diharapkan tidak akan melebar pada persoalan yang jauh dari subyek tersebut. Distribusi Dalam usaha untuk mencapai tujuan dan sasaran perusahaan di bidang pemasaran, setiap perusahaan melakukan kegiatan penyaluran. Penyaluran merupakan kegiatan pemyampaian produk sampai ke tangan si pemakai atau konsumen pada waktu yang tepat.

Beberapa pengertian mengenai saluran distribusi yang berkaitan dengan saluran distribusi oleh pakar di bidangnya sebagai berikut : Menurut Tjiptono (2014:295), "Saluran distribusi merupakan serangkaian partisipan organisasional yang melakukan semua fungsi yang dibutuhkan untuk menyampaikan produk/jasa dari penjual ke pembeli akhir". Oleh karena itu saluran distribusi dibutuhkan karena adanya perbedaan yang menimbulkan celah-celah atau kesenjangan di antara produksi dan konsumsi. Jenis Saluran Distribusi Menurut Stanton (2012:175) "Saluran distribusi dibedakan menjadi saluran distribusi untuk barang konsumsi, untuk barang industri dan untuk jasa".

Menurut Sigit dalam Sunyoto (2013:175) Prosedur menentukan saluran distribusi pada umumnya sebagai berikut :

a. Melakukan analisis terhadap produk yang akan dipasarkan untuk menetukan sifatsifat dan gunanya.

b. Menentukan sifat-sifat produk dan luasnya pasar.

c. Melakukan market survey untuk mengetahui pendapat-pendapat pembeli dan perantara mengenai saluran distribusi yang dipergunakan oleh pesaing. Promosi merupakan salah satu kegiatan pemasaran yang penting bagi perusahaan dalam upaya mempertahankan kelangsungan hidup perusahaan serta meningkatkan kualitas penjualan untuk meningkatkan kegiatan pemasaran dalam hal memasarkan barang atau jasa dari suatu perusahaan. Berikut beberapa menurut para ahli. Salah satu untuk membantu perusahaan dalam mengadakan komunikasi dengan konsumen adalah promosi dapat disampaikan informasi berupa pengetahuan mengenai produk yang ditawarkan. Berikut adalah pengertian promosi menurut para ahli: Kotler dan Armstrong (2014:76) mendefinisikan pengertian "promosi sebagai berikut, Promotion refers to activities that communicate to merits of the product and persuade target customers to buy it". Definisi tersebut menyatakan bahwa Promosi; "mengacu pada kegiatan berkomunikasi dua Merit produk dan membujuk pelanggan sasaran untuk pembeli". Rambat Lupiyoadi (2013:92) mendefinisikan pengertian promosi sebagai berikut, "Promosi adalah kegiatan yang dilakukan perusahaan untuk mengkomunikasikan manfaat produk dan sebagai alat untuk mempengaruhi konsumen dalam kegiatan pembelian atau penggunaan jasa sesuai dengan kebutuhan".

Pengertian Kepuasan Konsumen Menurut Kotler dan Keller yang dikutip oleh Bob Sabran (2012:177) "kepuasan konsumen adalah merupakan perasaan senang atau kecewa seseorang yang muncul setelah membandingkan antara kinerja atau hasil 

adalah perasaan senang atau kecewa seseorang yang muncul setelah membandingkan antara persepsi terhadap kinerja (hasil) suatu produk dengan harapan-harapanya". Selain itu, Daryanto dan Setyobudi (2014:43) mengatakan "kepuasan konsumen adalah suatu penilaian emosional dari konsumen setelah konsumen menggunakan produk dimana harapan dan kebutuhan konsumen yang menggunakannya terpenuhi". Berdasarkan beberapa di atas peneliti sampai pada pemahaman bahwa kepuasan konsumen adalah perasaan senang atau kecewa yang dirasakan konsumenatas pengalaman yang didapat dari produk yang ditawarkan oleh perusahaan dengan harapan keinginan dan kebutuhan dapat dipenuhi.

Hubungan Variabel Produk, Harga, Distribusi dan Promosi Terhadap Kepuasan Konsumen. Pengaruh produk merupakan pengaruh yang paling dominan terhadap keputusan pembelian, karena pengaruh langsungnya dibandingkan dengan pengaruh variabel bebas lainnya merupakan pengaruh yang terbesar. Dengan demikin variabel produk merupakan prioritas utama yang harus ditingkatkan untuk meningkatkan kepuasan konsumen. Untuk pengaruh harga adalah terbesar kedua setelah pengaruh produk. Ini menunjukan bahwa harga masih merupakan pengaruh yang dominan (setelah pengaruh produk) terhadap kepuasan konsumen. Dengan demikin variabel harga merupakan prioritas yang harus ditingkatkan (setelah prioritas produk) untuk meningkatkan kepuasan konsumen.

Pengaruh variabel distribusi ini tidak sebesar pengaruh produk dan harga, namun masih lebih besar dibandingkan pengaruh promosi. Ini menunjukan bahwa distribusi masih merupakan mengaruh yang signifikan (setelah pengaruh produk dan harga) terhadap kepuasan konsumen. Dengan demikin variabel distribusi merupakan prioritas yang harus ditingkatkan (setelah prioritas produk dan harga) untuk meningkatkan kepuasan konsumen. Pengaruh promosi ini merupakan pengaruh yang terbesar, hal ini diantara lain disebabkan promosi pada saat menjelang akhir tahun atau hari raya besar A\&W Restaurant memberikan diskon besar-besaran terhadap konsumen. Dengan demikian variabel promosi juga harus ditingkatkan (setelah prioritas terhadap produk, harga, dan distribusi) untuk meningkatkan kepuasan konsumen.

\section{HASIL ANALISIS DAN PEMBAHASAN}

Berdasarkan objek penelitian, baik tempat maupun sumber data, jenis penelitian ini termasuk penelitian lapangan. Metodeyang digunakan adalah metode kualitatif dengan pendekatan deduktif. Objek penelitian tidak hanya dilihat pada hal-hal empirik saja, tetapi juga mencakup fenomena yang tidak menyimpang dari persepsi, pemikiran, kemauan dan keyakinan suyek tentang sesuatu yang terjadi diluar subyek.

Jenis penelitian ini adalah studi deskriptif analitik, dimana seorang peneliti berusaha menggambarkan kegiatan penelitian yang dilakukan pada objek tertentu secara jelas dan sistematis yang mendeskripsikan dan menganalisis fenomena, peristiwa, aktifitas sosial, sikap, kepercayaan, persepsi dan pemikiran orang baik secara individual maupun kelompok, dengan cara deskripsi dalam kata-kata dan bahasa, pada suatu kontek khusus, alamiah dan memanfaatkan berbagai metode ilmiah. 
Pendekatan deduktif kuallitatif berusaha memahami arti peristiwa yang terjadi dalam situasi tertentu. Maka menurut pemahaman pandangan tersebut peneliti harus masuk dalam dunia konseptual suatu objek yang diteliti sedemikian rupa sehingga mengerti apa dan bagaimana suatu pengertian itu dibangun (moleong, 2008:6).

\section{SIMPULAN DAN SARAN}

Berdasarkan hasil penelitian di A\&W Restaurant Giant Maspion Square periode 20152018, maka dapat ditarik kesimpulan beberapa point penting dari keseluruhan isi dari karya tulis dibawah ini : Produk, dari hasil analisis produk di periode 2015-2018, di tahun 2015 hanya terdapat produk pokok saja tidak ada inovasi produk, inovasi produk dimulai dari 2016 sampai 2018 dengan mengikuti tren dan jaman dengan inovasi ini dapat mempengaruhi tingkat kepuasan konsumen yang ada di A\&W Restaurant Giant Maspion Square Margorejo, Surabaya. Harga, dari hasil analisis harga di periode 2015-2018, di tahun 2015 harga masih terjangkau dan mengalami kenaikan harga dimulai tahun 2016 dikarenakan naiknya harga bahan baku untuk pelengkap terjadinya proses produksi di A\&W Restaurant, dengan adanya kenaikan harga ada sebuah kebijakan untuk menjaga kepuasan konsumen, kebijakan tersebut adalah tidak merubah rasa dan tidak mengurangi porsi dari produk yang ada di A\&W Restaurant. Distribusi, analisis distribusi di periode 2015-2018, di tahun 2015 A\&W Restaurant belum bekerja sama dengan pihak ojek online hanya mengandalkan dari delivery order, pada tahun 2016 dimulainya bekerja sama dengan dengan ojek online yang pertama yaitu bekerja sama dengan pihak gojek, lalu ditahun 2017-2018 pihak perusaaan mengadakan kerja sama dengan pihak grab. Promosi, analisis promosi di periode 2015-2018, di tahun 2015 A\&W Restaurant sudah meluncurkan promo by one get one pada tanggal 1-5 januari dan promo mini kupon pada tanggal 1-30 november, ditahun 2016 promo by one get one berlaku pada tanggal 1-15 mei, pada bulan mei promo by one get one lebih lama dibandingkan bulan januari dan promo mini kupon pada tanggal 1-30 november. Di tahun 2017 A\&W Restaurant hanya mengeluarkan promo mini kupon saja yaitu pada tanggal 1-31 maret, pada tahun 2018 A\&W Restaurant hanya mengeluarkan promo mini kupon saja pada tanggal 1-30 oktober. Dilihat dari hasil survei melalui beberapa variabel $\mathrm{X}$ sebuah kepuasan konsumen bisa dinilai melalui Produk, Harga, Distribusi, dan Promosi. Di awal tahun 2015 terjadi sedikit saran dari pihak konsumen untuk membuat suatu inovasi produk supaya konsumen tidak jenuh dengan produk yang lama. Untuk harga tidak mengalami komplain dari konsumen karena dari segi harga sesuai dengan produk yang ditawarkan sehingga konsumen tidak berpaling ke Restaurant lain. Dari segi distribusi sangat lamban pada periode 2015 dikarenakan A\&W Restaurant belum bekerja sama dengan pihak ojek online kemudian di periode selanjutnya 2016-2018 A\&W Restaurant telah bekerja sama dengan pihak ojek online dikarenakan dari pihak konsumen menginginkan pelayanan yang mudah, praktis dan cepat. Sehingga konsumen merasa puas dengan adanya pelayanan terbaru dari pihak A\&W Restaurant dan ojek online Indonesia. Dari segi promosi sendiri A\&W Restaurant pada periode 2015 sudah ada promosi untuk pembelian suatu produk, promosi ini selalu diadakan pada setiap periode dengan jangka waktu tertentu, sehingga membuat konsumen merasa di untungkan. Berdasarkan hasil penelitian yang telah dilakukan maka diajukan saran sebagai berikut : Pihak Manager Restaurant A\&W Giant Maspion Square Margorejo, Surabaya sebaiknya tetap menjaga 
stabilitas dalam segi kepuasan konsumen secara beberapa faktor diantaranya produk, harga, distribusi, promosi. Pada perusahaan A\&W Restaurant yang banyak menerima komplain dari konsumen adalah harga dan promosi. Oleh sebab itu saran untuk Manager Restaurant sebaiknya harga harus sesuai dengan kualitas produk yang dijual, pada saat kenaikan harga seharusnya pihak A\&W Restaurant harus sesuai dengan pasar dan kompotitor supaya konsumen tidak berpindah ke merek yang lain, untuk titik kelemahan yang kedua adalah promosi, saran untuk Manager Restaurant sebaiknya A\&W Restaurant sering-sering melakukan sebuah promosi untuk menarik konsumen dari luar supaya meningkatkan sales di setiap harinya, dengan cara memberikan promo di setiap bulannya, pada saat ada acara party di Restaurant masing - masing anak diberikan hadiah oleh pihak perusahaan supaya terkesan lebih menarik dan memberi diskon untuk pelanggan tetap.

\section{DAFTAR PUSTAKA}

Alma, Buchari. (2011). Manajemen Corporate Strategi dan Pemasaran Jasa Pendidikan. Alfabeta, Bandung.

Alma, Buchari. (2013). Manajemen Pemasaran dan Pemasaran Jasa, Alfabeta, Bandung.

Amstrong, dan Kotler .(2012). Prinsip-prinsip Pemasaran. Edisi 12. Jilid 1. Erlangga, Jakarta.

Amstrong, dan Kotler .(2012). Prinsip-prinsip Pemasaran. Edisi 13. Jilid 1. Erlangga, Jakarta

Amstrong, dan Kotler. ( 2014). Principles Of Marketing, Edisi 15

Daina, dan Tjiptono.(2016). Service, Quality dan Satisfaction, Andi, Yogyakarta.

Daryanto. (2011). Manajemen Pemasaran: Sari Kuliah, Satu Nusa, Bandung.Etzel 2013,

Gito Sudarmo.(2012). Manajemen Pemasaran, Edisi 2, BPFE, Yogyakarta.

Keller, dan Kotler . (2012). Manajemen Pemasaran, Edisi 12, Erlangga, Jakarta.

Keller, dan Kotler .(2016). Marketing Manajemen, Edisi 15,Pearson Education, Inc

Tjiptono. (2014). Pemasaran Jasa-prinsip, Penerapan, dan Penelitian, Andi Offset, Yogyakarta.

Tjiptono, Fandy.(2012). Strategi Pemasaran, Andi, Yogyakarta. 